\title{
Kronična avtoimunska koprivnica pri otrocih
}

\section{Chronic Autoimmune Urticaria in Children}

Lana Stergar, Anja Koren Jeverica, Štefan Blazina

\section{Izvleček}

Koprivnica je v otroškem obdobju pogosta bolezen, za katero je značilno pojavljanje prehodnih srbečih koprivk, ki jih lahko spremlja angioedem. V večini primerov se koprivke nehajo pojavljati v nekaj dneh ali tednih, občasno pa koprivnica traja dlje. Če vztraja večino dni v tednu vsaj šest tednov, gre za kronično koprivnico. Kronično koprivnico razdelimo na dva glavna tipa, in sicer na kronično inducibilno koprivnico, pri kateri specifičen sprožilni dejavnik poznamo, in na kronično spontano koprivnico, pri kateri sprožilni dejavnik ni znan. Eden izmed mehanizmov pri kronični spontani koprivnici je avtoreaktivnost, pri kateri so prisotna avtoprotitelesa, največkrat usmerjena proti visokoafinitetnemu receptorju lgE in redkeje proti lastnim imunoglobulinom tipa IgE. Koprivnica se lahko pojavi tudi v sklopu nekaterih drugih bolezni, kot so makulopapulozna kožna mastocitoza, angioedem, posredovan z bradikininom, urtikarijski vaskulitis, sistemska mastocitoza in nekateri avtoinflamatorni sindromi. Ta stanja zaradi redkosti pogosto pozno prepoznamo, v primeru zamude pri zdravljenju pa lahko pride do nepopravljive okvare (npr. okvara ledvic pri urtikarijskem vaskulitisu). Nekatere bolezni s pridruženo kronično koprivnico lahko zdravimo usmerjeno, npr. avtoinflamatorne bolezni z blokado interlevkina 1. Kronično spontano koprivnico zdravimo z antihistaminiki, ki jim v primeru nezadostne učinkovitosti kljub povišanemu odmerku lahko dodamo omalizumab. $\mathrm{V}$ primeru rezistentne kronične koprivnice lahko dodamo še druga imunosupresivna zdravila.

Ključne besede: koprivnica, otrok, kronična koprivnica, avtoinflamatorna bolezen, zdravljenje, omalizumab. 


\section{Uvod}

Urtikarija ali koprivnica je pogosta bolezen, za katero so značilni eritematozni, od podlage dvignjeni plaki različnih velikosti. Koprivke so običajno srbeče, včasih pekoče, redko hemoragične in se tipično selijo po različnih mestih na koži. Izpuščaj je značilno prehoden, po 30 minutah do 24 urah izgine, nato pa je koža na tem mestu spet normalnega izgleda. Koprivnico lahko spremlja angioedem, to je globlji edem dermisa in podkožnega tkiva ali sluznice, za katerega je značilen nenaden pojav otekline, najpogosteje ustnic, vek, dlani oziroma stopal. Redko srbi, včasih boli. Izzveni počasneje kot koprivka, lahko šele v 72 urah. Koprivnica se pojavi zaradi degranulacije dermalnih in submukoznih mastocitov, ki sproščajo vazoaktivne vnetne posrednike, kot so histamin in lipidni posredniki (levkotrieni in prostaglandini), ti pa nato ojačajo izražanje ostalih citokinov in kemokinov ter sprožijo ekstravazacijo tekočine v povrhnja tkiva. Koprivke so primarne spremembe pri kronični spontani koprivnici, lahko pa jih vidimo tudi pri nekaterih drugih stanjih, kot so makulopapulozna kožna mastocitoza (prej imenovana urticaria pigmentosa), angioedem, posredovan z bradikininom, urtikarijski vaskulitis, sistemska mastocitoza in nekateri avtoinflamatorni sindromi (npr. s kriopirinom povezani periodični sindromi). Koprivnica je glede na trajanje akutna ali kronična. Diagnozo kronična koprivnica postavimo, ko so koprivke z angioedemom ali brez angioedema prisotne več kot 6 tednov in večino dni v tednu. Vsaj enkrat v življenju ima akutno koprivnico kar 20 \% ljudi, kronična je manj pogosta, kakovost življenja pa izrazito slabša.

Kronično koprivnico delimo na dva glavna tipa, in sicer na kronično inducibilno koprivnico z znanim specifičnim sprožilnim dejavnikom ter na kronično spontano koprivnico, pri kateri sprožilnega dejavnika ne poznamo. Med kronične inducibilne koprivnice uvrščamo simptomatski dermatografizem (t. i. urticaria factitia), koprivnico na mraz, koprivnico na toploto, pozno koprivnico na pritisk, solarno koprivnico, vibratorni angioedem, holinergično koprivnico, kontaktno koprivnico in akvageno koprivnico. $V$ zadnjih desetletjih ugotavljajo tudi vedno več vzrokov za pojav kroničnih spontanih koprivnic, ki so pred tem veljale za idiopatske; pomemben vzrok so akutne ali kronične okužbe (npr. Helicobacter pylori ali Anisakis simplex). Eden izmed možnih mehanizmov pri kronični spontani koprivnici je tudi avtoimunost, pri kateri so prisotna funkcionalna protitelesa tipa IgG, usmerjena proti visokoafinitetnemu receptorju IgE, ali protitelesa proti lastnim imunoglobulinom tipa IgE (2).

\section{Epidemiologija in etiologija kronične avtoimunske koprivnice pri otrocih}

Razširjenost kronične koprivnice pri otrocih je 0,1-13,0\%; v vaj $30 \%$ je avtoimunska, $v$ večini primerov posredovana s protitelesi IgG proti receptorju za IgE, v manjšem deležu pa proti samemu IgE (4-7). Nastanek protiteles antiFceRla pri genetsko predisponiranih posameznikih v nekaterih primerih povezujejo z okužbo z bakterijo Helicobacter pylori. Lahko bi šlo za molekularno mimikrijo bolnikovih antigenov (FcERI) s saharidnim delom lipopolisaharidov te bakterije (8). Tudi bolezen ščitnice lahko sproži kronično koprivnico, predvsem $z$ aktivacijo komplementnega sistema. Zdravljenje tiroiditisa lahko privede do remisije kronične koprivnice. Najpomembnejše je genetsko nagnjenje $k$ avtoimunosti (9).

\section{Patogeneza kronične avtoimunske koprivnice}

$\checkmark$ patogenezi kronične avtoimunske koprivnice so pomembna protitelesa anti-lgE in anti-FceRI, ki aktivirajo bazofilce in mastocite, izpuščaj pa vzdržuje tudi aktivacija komplementa (C5a). Visokoafinitetni IgE-receptor FcERI je sestavljen iz štirih peptidnih verig. Veriga a ima zunajcelični del, kjer je vezavno mesto za IgE. Tja se vežejo tudi IgG-protitelesa anti-FcદRI, ki navzkrižno povežejo in dimerizirajo receptor, kar vodi do aktivacije mastocita/bazofilca in sproščanja histamina ter ostalih mediatorjev. Manjši del bolnikov, tj. 5-10\% bolnikov s kronično avtoimunsko koprivnico, ima avtoprotitelesa, specifična za IgE. Ta se povežejo $z \lg E$, vezanim na receptor, ter $z$ navzkrižno povezavo in dimerizacijo receptorja povzročijo sproščanje histamina $(4,6)$. Vezava enih ali drugih avtoprotiteles in dimerizacija mastocitnega receptorja za IgE povzročita tudi aktivacijo klasične poti komplementa in tvorbo $\mathrm{C} 5 \mathrm{a}$, ki je pomemben pri aktivaciji dermalnih mastocitov $(4,6,7)$ ter deluje kot kemoatraktant nevtrofilcev in eozinofilcev, kar povzroča kopičenje teh celic $v$ koži sprememb $(4,6)$. Dermalni mastociti izločajo vnaprej sintetizirane posrednike vnetja, kot so histamin, proteaze, interlevkin-1 in tumor nekrotizirajoči faktor a (TNF-a). Ti citokini povzročajo povečano izražanje adhezijskih molekul endotela postkapilarnih venul. De novo sintetizirani posredniki vključujejo levkotriene, prostaglandine, citokine in kemokine, ki privabljajo levkocite, vključno z eozinofilci, ki so značilni za reakcijo pozne faze (4).

\section{Povezava $\mathrm{z}$ avtoimunskimi boleznimi}

Obstaja več posrednih dokazov, ki pri kronični koprivnici nakazujejo na avtoimunsko etiologijo. To so povezanost z ostalimi avtoimunskimi boleznimi, infiltracija limfocitov $T \mathrm{v}$ povrhnjem in srednjem dermisu s perivaskularno distribucijo, avtoreaktivnost bolnikovega seruma, povezava s specifičnim MHC haplotipom (npr. HLA-DR4 in DQB1*0301/4) in ugoden odziv na imu- 
nosupresijo $(8,9)$. Med pridruženimi avtoimunskimi boleznimi je pri bolnikih s kronično avtoimunsko koprivnico najpogostejša bolezen ščitnice $(1,9)$.

Ostale avtoimunske bolezni, ki se pogosteje pojavljajo pri bolnikih s kronično avtoimunsko koprivnico, so diabetes mellitus tipa 1, kronična vnetna črevesna bolezen, sistemski juvenilni idiopatski artritis, sistemski eritematozni lupus, celiakija, vitiligo, perniciozna anemija, avtoimunski artritis in Sjögrenov sindrom. Kronična koprivnica je opisana tudi pri bolnikih z avtoimunskim poliglandularnim sindromom. Pri številnih bolnikih z avtoimunsko koprivnico ugotavljamo prisotnost revmatoidnega faktorja (RF) in protijedrnih protiteles (ANA). Pogosto, pri približno $43 \%$ bolnikov, lahko pri kronični koprivnici dokažemo tudi protitelesa proti C1q, ki so značilna za bolnike z urtikarijskim vaskulitisom, pa tudi (z različno razširjenostjo) za bolnike z drugimi boleznimi, kot so vaskulitis, povezan z okužbo (npr. s hepatitisom C), avtoimunske bolezni, kot so lupusni nefritis, nodozni poliarteritis, gigantocelični arteritis, Behçetova bolezen in s krioglobulinom povezan vaskulitis $(3,10)$. Te povezave podpirajo teorijo, da bolniki razvijejo kronično avtoimunsko koprivnico zaradi prirojene nagnjenosti k avtoimunosti $(8,9,11)$.

\section{Diagnosticiranje pri sumu na kronično avtoimunsko koprivnico}

Avtoimunsko etiologijo kronične koprivnice potrjujejo pozitiven biološki test (test aktivacije bazofilcev, BAT) za dokaz patogeneze in vitro, pozitivna avtoreaktivnost (pozitiven avtologni serumski kožni test, ASST) za dokaz relevantnosti degranulacije mastocitov in vivo ter pozitiven imunološki test za specifična avtoprotitelesa IgG proti FceRla in/ali anti-IgE (Western blot (WB) ali ELISA) za dokaz protitelesne specifičnosti (7). Te preiskave izvaja- mo le v eksperimentalne namene, v rutinski klinični uporabi pa zaradi enakega zdravljenja avtoimunske koprivnice in ostalih vrst kronične spontane koprivnice, ki ne prizadene notranjih organov, intenzivnega in dragega diagnosticiranja ne izvajamo (2). Med ostalimi laboratorijskimi najdbami pri bolnikih s kronično avtoimunsko koprivnico lahko opažamo pomembno nižja celokupna serumska protitelesa lgE in tudi nizko število bazofilcev v krvi, saj so sekvestrirani v kožnih spremembah. Ob remisiji bolezni in zdravljenju z omalizumabom lahko opažamo njihov porast. Znano je tudi, da so ravni D-dimera pomembno višje pri bolnikih s kronično avtoimunsko koprivnico in se znižajo $v$ skladu s kliničnim odzivom bolezni na omalizumab. Za zdaj omenjenih laboratorijskih najdb ne uporabljamo za diagnosticiranje ali spremljanje aktivnosti bolezni $(2,4)$. Pri kožni biopsiji so histomorfološke značilnosti kože pri kronični avtoimunski koprivnici podobne kot pri pozni alergijski reakciji, le z nekoliko bolj izraženim granulocitnim infiltratom. Te majhne razlike so premalo značilne za uporabo pri diagnosticiranju, vsekakor pa se histopatološka slika razlikuje od levkocitoklastičnega vaskulitisa, ki je viden pri urtikarijskem vaskulitisu in včasih tudi pri avtoinflamatornih boleznih $(4,12)$.

Diagnostične preiskave za potrditev avtoimunske etiologije koprivnice torej niso smiselne, so pa včasih potrebne za izključitev bolezni, ki lahko posnemajo kronično avtoimunsko koprivnico.

\section{Diferencialno diagnosticiranje kronične avtoimunske koprivnice}

Preiskave pri bolnikih s kronično koprivnico opravljamo stopenjsko. Povišane vrednosti vnetnih parametrov in patološki urin lahko kažejo na okužbo ter avtoimunsko ali avtoinflamatorno bolezen. Eozinofilija lahko kaže na prisotnost okužbe s paraziti (2). Pri bolnikih s patološkimi izvidi osnovnih preiskav $v$ imunoloških ambulantah opravimo še dodatne preiskave, kot so komplement, koncentracija protiteles proti C1q, včasih tudi histopatološki pregled biopsije kožne lezije za opredelitev možnosti urtikarijskega vaskulitisa, ki lahko hitro povzroči nepovratno okvaro ledvic (12-14). Pri otroku moramo biti med diferencialnodiagnostičnimi možnostmi posebej pozorni na morebitne avtoinflamatorne bolezni, kot so s kriopirinom povezani periodični sindromi s povečanim izločanjem interlevkina 1, medtem ko se $z$ receptorjem za TNF povezan avtoinflamatorni sindrom lahko pojavi šele v odraslosti. Urtikarijski vaskulitis s prizadetostjo notranjih organov zdravimo z imunosupresivnimi zdravili, avtoinflamatorne bolezni pa z usmerjenim zaviranjem citokinov, največkrat interlevkina $1(2,15)$. Tudi virusne, bakterijske, parazitne ali glivične okužbe, npr. s $H$. pylori, streptokoki, stafilokoki, Yersinio, Giardio lamblio, Mycoplasmo pneumoniae, virusi hepatitisa, norovirusom, parvovirusom B19 ter povzročitelji Anisakis simplex, Entamoeba spp, Blastocysta spp., lahko povzročajo kronično koprivnico. Kronično koprivnico lahko posnema tudi ponavljajoča se akutna koprivnica, pri kateri sprožitelja akutne koprivnice nismo identificirali in ga odstranili. Dalj časa trajajočo koprivnico lahko sprožijo tudi fizikalni dejavniki. Rutinsko presejanje na maligne bolezni pri diagnosticiranju vzrokov za koprivnico ne svetujemo (2).

\section{Zdravljenje kronične koprivnice}

Po smernicah EAACI/GA²LEN/EDF/WAO iz leta 2018 je za otroke s kronično koprivnico prva izbira zdravljenja redno prejemanje $\mathrm{H} 1$-antihistaminikov druge generacije, kot so cetirizin, loratadin, feksofenadin, desloratadin in rupatadin. Če po 2-4 tednih 
H1-antihistaminik druge generacije

Če nezadosten učinek, po 2-4 tednih ali prej, če so simptomi neznosni

Povišaj odmerek H1-antihistaminika druge generacije do $4 x$ druge generacije

Če nezadosten učinek, po 2-4 tednih ali prej, če so simptomi neznosni

H1-antihistaminik druge generacije dodaj omalizumab (specialist)

Če nezadosten učinek, po 6 mesecih ali prej, če so simptomi neznosni

H1-antihistaminiku druge generacije dodaj ciklosporin (specialist)

SLIKA 1. PROTOKOL ZDRAVLJENJA KRONIČNE KOPRIVNICE PO NOVIH SMERNICAH EAACI/GA²LEN/ EDF/WAO.

FIGURE 1. THE EAACI/GA²LEN/EDF/WAO GUIDELINES FOR TREATMENT OF CHRONIC URTICARIA.

\begin{tabular}{lll} 
Točke & Koprivke & Srbenje \\
\hline 0 & nič & nič \\
\hline 1 & blage (<20 koprivk/24 ur) & blago (prisotno, a ne nadležno ali moteče) \\
\hline 2 & zmerne (20-50 koprivk/24 ur) & $\begin{array}{l}\text { zmerno (moteče, a ne vpliva na normalne } \\
\text { dnevne dejavnosti ali spanje) }\end{array}$ \\
\hline 3 & $\begin{array}{l}\text { intenzivne (> 50 koprivk/24 ur ali velika } \\
\text { zlivajoča se področja koprivk) }\end{array}$ & $\begin{array}{l}\text { intenzivno (hudo srbenje, dovolj moteče, } \\
\text { da vpliva na normalne dnevne dejavnosti } \\
\text { ali spanje) }\end{array}$ \\
\hline
\end{tabular}

TABELA 1. OCENJEVALNA LESTVICA »TOČKOVNIK AKTIVNOSTI KOPRIVNICE« (UAS7). TABLE 1. "THE URTICARIA ACTIVITY SCORE« (UAS7) ni izboljšanja, svetujemo povišanje odmerka za 2- do 4-krat. Bolnikom, ki na tovrstno zdravljenje ne odgovorijo, lahko uvedemo omalizumab, ki je anti-IgE monoklonsko protitelo in ga priporočajo kot zdravilo druge izbire $(1,2,16)$. Omalizumab je biološko zdravilo, ki ga vbrizgamo pod kožo (13). Je rekombinantno humanizirano monoklonsko protitelo IgG1, ki se veže na konstantno regijo protitelesa IgE, s čimer prepreči interakcijo med prostim IgE in visokoafinitetnimi receptorji IgE. To vodi do znižanja izražanja visokoafinitetnih IgE receptorjev na mastocitih in bazofilcih $(1,17)$. Vnetni odziv se zmanjša, pride tudi do znižanja cirkulirajočega interlevkina 6 in TNF-a ter do zmanjšanega kopičenja celic $T$, eozinofilcev in makrofagov. Vse to vodi do preprečevanja koprivnice in angioedema $(2,17)$. Izboljšanje simptomov lahko opazimo že po prvem odmerku, a je za preprečevanje ponovitev in za popolno remisijo potrebnih več odmerkov. Omalizumab je po dosedanjih podatkih varno zdravilo z malo neželenimi učinki (predvsem blage kožne reakcije na mestu vboda in redko anafilaksija), a širšo uporabo omejuje visoka cena (1).

Pri bolnikih, pri katerih ne dosežemo zadostnega izboljšanja s kombinacijo visokega odmerka antihistaminikov $\mathrm{H} 1$ druge generacije in omalizumaba ali zanje omalizumab ni dostopen, lahko poskusimo z drugimi imunomodulirajočimi zdravili, na primer s ciklosporinom, mikofenolat mofetilom, dapsonom, sulfasalazinom in hidroksiklorokinom $(1,2,18)$. Ker ciklosporin A ni registriran za zdravljenje koprivnice, zdravljenje z njim priporočamo samo pri bolnikih s hudo refraktorno boleznijo ob neuspešnem zdravljenju z visokim odmerkom antihistaminika in omalizumaba (2). Raven dokazov za učinkovitost adjuvantnega zdravljenja $z$ antagonisti levkotrienskih receptorjev pri koprivnici je nizka, še najboljša pri montelukastu (2). Zaradi neželenih učinkov bolnikom s kronično koprivnico odsvetujemo dolgotrajno prejemanje sistemskih 
kortikosteroidov, topikalni pa žal niso učinkoviti. Kratkotrajno prejemanje oralnih kortikosteroidov pride v poštev le za prehodno lajšanje zelo izrazite koprivnice z otekanjem, ki onemogoča normalno življenje $(1,2)$. Zmanjšanje števila funkcionalnih avtoprotiteles $s$ plazmaferezo je prehodno koristno pri nekaterih hudo prizadetih bolnikih (2). Glede učinkovitosti antagonistov $\mathrm{H}_{2}$ in dapsona, ki so jih priporočali nekoč, ni dovolj dokazov, da bi jih priporočili v algoritmu, a so zaradi nizke cene dostopna možnost (2). V nedavni raziskavi so dokazali, da je dapson lahko učinkovito in varno zdravilo druge izbire pri bolnikih s kronično spontano koprivnico (7). Za uporabo sulfasalazina, metotreksata, interferona, fototerapije, intravenskih imunoglobulinov in drugih v literaturi ni dovolj trdnih dokazov o njihovi učinkovitosti ali pa so bile objavljene le serije primerov. Glede ostalih bioloških zdravil poleg omalizumaba preučujejo tudi možnost uporabe ligelizumaba, ki je visokoafinitetno humanizirano monoklonsko anti-IgE-protitelo naslednje generacije in je po nekaterih raziskavah celo bolj učinkovit od omalizumaba. Preučujejo tudi uporabo rituksimaba in drugih zdravil, ki delujejo na limfocite B $(18,19)$. Pri kronični koprivnici svetujemo zdrav življenjski slog, ki vključuje izogibanje stresu, pretirani utrujenosti, uživanju alkohola in nesteroidnih protivnetnih zdravil, ter oprijetim oblačilom. Srbenje lahko olajšamo s hladno prho in z vzdrževanjem hladne temperature $v$ spalnici. Lahko uporabimo tudi hladilne losjone (4).

\section{Ocenjevanje aktivnosti bolezni in vpliva na bolnika}

Aktivnost bolezni pri kronični koprivnici lahko ocenimo z ocenjevalno lestvico UAS7 (angl. The Urticaria Activity Score) (Tabela 1). temelji na oceni ključnih znakov in simptomov koprivnice (koprivke in srbenje), ki jih zabeleži bolnik. Aktivnost koprivnice se pogosto spreminja, zato bolniku svetujemo, da si vsak dan, več dni zapored, zapiše 24-urno oceno težav. UAS7 je vsota točk sedmih zaporednih dni, s katero naj bi v klinični praksi rutinsko ocenili aktivnost bolezni in odziv na zdravljenje pri bolnikih s kronično spontano koprivnico (2). Vsota točk $<7 \mathrm{v}$ enem tednu pomeni dobro nadzorovano bolezen, medtem ko $>28$ točk $v$ enem tednu pomeni intenzivno (neobvladano?) bolezen (17). Za bolnike $z$ angioedemom so razvili in ovrednotili novo lestvico aktivnosti bolezni (angl. Angioedema Activity Score). V zadnjem času kot retrospektivni vprašalnik uporabljajo test spremljanja koprivnice (angl. Urticaria Control Test), ki so ga razvili za določanje ravni nadzora nad boleznijo pri vseh oblikah kronične koprivnice. O dobrem nadzoru nad boleznijo govorimo pri vsoti 12 od 16 možnih točk. Ocena lahko pomaga pri odločitvah glede prilagajanja zdravljenja. Poleg aktivnosti bolezni in nadzora nad boleznijo je smiselno ocenjevati tudi vpliv bolezni na kakovost življenja, kar lahko storimo z vprašalnikom o kakovosti življenja s kronično koprivnico (angl. Chronic Urticaria Quality of Life Questionnaire) in z vprašalnikom resnosti koprivnice (angl. Urticaria Severity Score) (16). Omenjena vprašalnika bi bilo smiselno uporabljati ob vsakem obisku bolnika s koprivnico, saj pomaga pri odločanju glede nadaljnjega zdravljenja (2).

\section{Zaključek}

Kronična avtoimunska koprivnica je pri otrocih sicer redko stanje, a pomembno poslabša kakovost življenja, saj je zdravljenje $z$ antihistaminiki običajno slabo učinkovito. Otroci s kronično ali ponavljajočo se koprivnico imajo lahko tudi okužbo in avtoimunsko ali avtoinflamatorno bolezen, ki lahko neprepoznana ali nezdravljena vodi $v$ trajne okvare organov. Pri otrocih, pri katerih z višjim odmerkom antihistaminika ne dosežemo zadovoljivega izboljšanja, po novih smerni- cah kot zdravilo druge izbire dodamo še varno in učinkovito zdravilo omalizumab ali imunosupresivna zdravila. Učinek zdravljenja ocenjujemo klinično in z vprašalniki, kar nam pomaga pri bolj učinkovitem odločanju o zdravljenju in s tem $\mathrm{k}$ čim manjšemu vplivu bolezni na bolnikovo življenje.

\section{Literatura}

1. Del Pozzo-Magaña BR. Emj European Medical Journal Chronic Urticaria in Children: a Review. Cit. EMJ Dermatol 2017; 5(1): 74-82.

2. Zuberbier $T$, Aberer $W$, Asero R, Abdul Latiff AH, Baker D, Ballmer-Weber B, et al. The EAACI/ GA2LEN/EDF/WAO guideline for the definition, classification, diagnosis and management of urticaria. Allergy Eur. J Allergy Clin Immunol 2018; 73(7): 1393-414.

3. Jayakanthan K, Gupta AN, Mathew J, Ravindran R, Mahasampth G, Danda D. Clinical utility of anti-C1q antibody in primary and secondary vasculitic conditions. Int J Health Sci (Qassim) 2017; 11(5): 3-6.

4. Goh C, Tan K. Chronic autoimmune urticaria : Where we stand? Indian J Dermatol 2009; 54(3): 269-74

5. Brunetti L, Francavilla R, Miniello VL, Platzer $M H$, Rizzi D, Lospalluti ML, et al. High prevalence of autoimmune urticaria in children with chronic urticaria. J Allergy Clin Immunol 2004; 114(4): 922-7.

6. Kikuchi Y, Kaplan AP. A role for C5a in augmenting IgG-dependent histamine release from basophils in chronic urticaria. J Allergy Clin Immunol 2002; 109(1): 114-8.

7. Liang SE, Hoffmann R, Peterson E, Soter NA Use of Dapsone in the Treatment of Chronic Idiopathic and Autoimmune Urticaria. JAMA Dermatol 2019; 155(1): 90-5.

8. Konstantinou GN, Asero R, Ferrer M, Knol EF, Maurer M, Raap U, et al. EAACI taskforce position paper: Evidence for autoimmune urticaria and proposal for defining diagnostic criteria. Allergy Eur J Allergy Clin Immunol 2013; 68(1): 27-36.

9. Fraser K, Robertson L. Chronic urticaria and autoimmunity. Skin Therapy Lett 2013; 18(7): 5-9.

10. Ramos-Prol A, Rubio-Almanza M, Campos-Alborg V, Febrer-Bosch I, Merino-Torres JF. Chronic autoimmune urticaria as a possible non endocrine manifestation of autoimmune polyglandular syndrome type II. Endocrinol y Nutr (English Ed. 2011; 58(9): 503-5.

11. Garmendia, J.V. et al. Anti-C1q antibodies in patients with chronic idiopathic urticaria. Journal of Allergy and Clinical Immunology 2004; 113(2): S257.

12. Wisnieski JJ. Urticarial vasculitis. Curr Opin Rheumatol 2000; 12(1): 24-31.

13. Rivas González AM, Velásquez Franco CJ, Pinto Peñaranda LF, Márquez JD. Urticaria Vas- 
culítica Rev Colomb Reumatol 2009. https://doi org/10.1016/S0121-8123(09)70114-8.

14. Roy K, Talukdar A, Kumar B, Sarkar S. Hypocomplementaemic urticarial vasculitis syndrome: A mimicker of systemic lupus erythematosus. BMJ Case Reports 2013; bcr2013009082.

15. Krause $K$, Grattan CE, Bindslev-Jensen $C$ Gattorno M, Kallinich T, De Koning HD, et al. How not to miss autoinflammatory diseases masquerading as urticaria. Allergy Eur. J Allergy Clin Immunol 2012; 67(12): 1465-74.

16. Kaplan AP, Joseph K, Maykut RJ, Geba GP, Zeldin RK. Treatment of chronic autoimmune urticaria with omalizumab. J Allergy Clin Immunol 2008; 122(3): 569-73.

17. Moolani $Y$, Lynde C, Sussman G. Advances in Understanding and Managing Chronic Urticaria. F1000Research 2016; 5(0): 177.

18. David A Khan, MD. Chronic spontaneous urticaria: Treatment of refractory symptoms. UpToDate; Literature review current throug Apr 2019. This topic last updated: May 10, 2019.

19. Arkwright PD. Anti-CD20 or anti-IgE therapy for severe chronic autoimmune urticaria. J. Allergy Clin. Immunol. [Internet]. American Academy of Allergy, Asthma \& Immunology; 2009; 123(2): 510-1.

20. Maurer M, Giménez-Arnau AM, Sussman G, Metz M, Baker DR, Bauer A, et al. Ligelizumab for Chronic Spontaneous Urticaria. N Engl J Med 2019; 381(4): 1321-32
Lana Stergar, dr. med.

(kontaktna oseba / contact person)

Zdravstveni dom Koper

Koper, Slovenija

Anja Koren Jeverica, dr. med.

Služba za alergologijo, revmatologijo in klinično imunologijo,

Pediatrična klinika

Univerzitetni klinični center Ljubljana

Ljubljana, Slovenija

dr. Štefan Blazina, dr. med.

Služba za alergologijo, revmatologijo in klinično imunologijo,

Pediatrična klinika,

Univerzitetni klinični center Ljubljana,

Ljubljana, Slovenija

prispelo / recived: 9. 7. 2020

sprejeto / accepted: 3. 12. 2020

Stergar L, et. al. Kronična avtoimunska koprivnica pri otrocih. Slov Pediatr 2021; 28(1): 24-29. https://doi.org/10.38031/slovpediatr-2021-1-04. 